\title{
Goat Production in Oyo State: A case study of Ogbomoso town
}

\author{
* S.M. Odeyinka and G.K Okunade. \\ Department of Animal Science, Faculty of Agriculture Obafemi Awolowo University, Ile-Ife, \\ Nigeria. \\ E-mail: smodeyinka@yahoo.co.uk * Corresponding author:
}

\begin{abstract}
The study was conducted in two Local Government areas (LGAS) of Oyo State: Ogbomoso North and Ogbomoso South L.G.A. The study was carried out through the use of structured questionnaires. A total of 90 questionnaires were administered randomly in the two LGAS. Questions were asked based on background, production system, constraints to goat prt)duction t'. t.c of the respondents. The data were analyzed separately using descriptive analysis. The results showed that $95.2 \%$ of household owners of goat were females while the major farms employed male labour. West African Dwarf goat was the common breed of goat raised in the two LGAS. Majority of the household owners of goat practised free range system of production (86.7\%) while a lurge percentage of the major farms practiced intensive system of production (80\%). There were no specialized housing and feeding programmes, a larger percentage of both categories fed crop residues such as cassava peels, cornstarch meal residues, and cowpea husk to the goats. The household owners of goat seldom feed forage to their goats (20\%) while all the major farms fed forage to the goats.

The common diseases in the area were diarrhea, pneumonia and mange. No form of control breeding was practiced among the categories of goat keepers. There is a lack of extension service in the areas because majority of both the household owners (98\%) and major farms (60\%) did not have access to extensian agents. The constratints to goat production in the area inctude accidents on the road, seasonality of feed supply, diseases, theft, lack of capital and land.
\end{abstract}

Key Words: Goat production, Ogbomoso, Oyo-State

\section{Introduction}

The developing countries of the world have a daily animal protein intake that is below the Food and Agriculture Organization (FAO, 1985) standard of $25 \mathrm{~g}$. FAO (1986) reported that the protein intake per person has fallen from $50.9 \mathrm{~g}$ between $1979-1981$, to $45.0 \mathrm{~g}$ between 1983-
1985. In Nigeria, this amounts to only $10 \mathrm{~g}$ per day of animal protein intake (FAO, 1985). For an improved animal protein intake in Nigeria, there has to be an improvement in the production of meat and other protein sources from the livestock industry and goat production is a major part of the industry. 
Goats are mostly kept and reared by male farmers engage in food and tree crop production or women involved in food processing or marketing in the rural area. International Livestock Centre for Africa (ILCA)'s village surveys in southwest Nigeria indicated that up to $75 \%$ of the rural population keeps small ruminants with an average herd size of two to four animals per household, the goats being more commonly kept than the sheep (Sumberg and Cassaday, 1984, Sumberg and Mack, 1985). Similar pattern was observed in Osun state (Odeyinka, 1996), and in the in the Eastern part of Nigeria by Gefu et. al (1994). However, the mean flock sizes per household were 14.2 and 6.9 for goats and sheep respectively in old Bauchi state (Doma et.al; (1999) Goats are mostly kept on a part time basis to supplement the household main income and also for use during special occasions and festive seasons. According to Upton, (1987), goats in the humid tropics, are generally kept as a lowcost adjunct to arable and tree crop production.

The importance of goat production can be summarized as; small ruminants (sheep and goats) are sources of meat, which provide animal protein that is indispensable to a balanced human diet (Alimi, 1987). Goat meat enjoys wide acceptability among the different socio-cultural groups because there is a lack of taboo against goat meat (Peacock, 1996). Goat also produces milk, which has some medicinal advantages over cow's milk. Their small size relative to cattle contributes to their wide distribution and easy management among women and children who provide the bulk labour in small family farms. Goat serves as insurance against crop failure because they can quickly be converted to cash in times of financial need. They also have important drought survival strategy in marginal cropping area where mixed farming is prevalent (Doma et.al; (1999). Goats reproduce very fast with tropical breeds producing twins and some triplets. Hence, a small flock can quickly expand until it forms a major part of the family capital asset (Peacock, 1996). The goat is considered superior to other ruminant species in it's utilization of poor quality, high fibre forages (Howe et $a l, 1988$ and Dominique et $a l, 1991$ ) Hence, feed cost is relatively lower than when compared with mono-gastric animals, which could be up to $70 \%$ of the total cost of production.

There is no information in literature on Ogbomoso town as it relates to goat production. Most studies on small ruminant production have been carried out in the villages (Mattewman, (1977), Sumberg and Mack, (1985) and there is scanty information on urban production. There is therefore the need to evolve suitable production and management practices, so as to improve the performance of small ruminants in the area. The study was designed to ascertain the level of development of goat production in Ogbomoso town and to identify the major constraints affecting goat production in the area.

\section{Materials and Methods}

The study areas were Ogbomoso North and Ogbomoso South local government areas of Oyo state. The state is located in southwestern Nigeria. Ogbomoso north and Ogbomoso South are located between latitude $8^{\circ} 5^{\prime}$ and longitudes $4^{\circ} 11^{\prime}$ in southwestern Nigeria. They are in the savanna belt (derived) of Nigeria with an annual rainfall of about $1,250 \mathrm{~mm}$, a mean annüal temperature of about $26^{\circ} \mathrm{C}$ and a mean annual sunshine of about 2,000-2,250 hours. Major occupations of the people are trading, public service and farming. Many do combine farming with other occupation like tailoring, brick layering, transporting and embroidery making.

A total of 90 questionnures were distributed among the selected areas in the two local government areas. Ogbomoso North and 
Ogbomoso South. The selected areas were "Sabo", "Randa" and "Apake" in Ogbomoso north and "Caretaker", "Ahoyaya" and "Osupa" areas in Ogbomoso South. The areas were selected randomly and divided into streets. Five questionnaires were distributed per street. Fortyfive questionnaires were distributed per local government area. The major farms in the two local governments were also sampled; they were five in number. Out of the ninety questionnaires, 88 were collected back for analysis. The household owners of goats filled 83 questionnaires and the major farms in the areas filled five questionnaires.

Data obtained from the study (the two LGA combined) were analyzed using the descriptive statistics i.e. range, mean, frequency and percentages (SPSS for Ms Window release 6.0).

\section{Results and Discussion}

Two different sets of data were collected during the study. The first set was from five major farms in the areas and the second set from 83 household owners of goats in the areas. The results were analyzed separately and presented in tables 1 to 3.

Table 1 shows the background information of the respondents expressed in percentages and their absolute values. Goat production in Ogbomoso town is common among adults. Majority of household owners (95.2\%) were females while $4.8 \%$ were males. This is similar to the observation made under village production of goat (Sumberg and Cassaday, 1985). Majority of the major farms hire only male laborers to handle their goats $(80 \%)$. Majority of the respondents were educated, having a minimum of secondary education. This is in agreement with previous work conducted in peri-urban towns in
Osun-state (Odeyinka, 1996). About ninety-eight percent of the household owners of goats take goat production as a part time business while all of the major farms take goat production as a full time business.

Free-range system of management is the common method of production among the household owners $(86.7 \%$ ) while $80 \%$ of the major farms practised the intensive system of production. Majority of the household owners do not have houses for their goats, instead the goats sleep around thic houses and along the streets at night while majority of the major farms housed their animals in concrete floored houses. A large percentage of both the farms and household owners purchased their parent stock and the herd then increase through new births (kidding). However, the practice of contractual agreement was used by $31.8 \%$ of the household owners to enter the goat production business. Predominant among the reasons given for keeping goats are supplementation of income whereby the goats are sold mostly through a goat seller to the final consumer and for consumption during special occasions. Other reasons include the belief that goats are substitute victims for evil or sickness that is supposed to come upon members of the household. The mean flock size per household per LGA was 4.6 for the household owners and 32 for the major farms. This is an improvement over 2 to 4 which have been reported in literature for goat production in the villages (Sumberg and Mack, 1985).

All the major farms and $76.5 \%$ of the household owners received the services of veterinary personnel. The cost of treatment collected from the major farms and household owners was \#487.00 and \#140.00 respectively per farm per year. The common diseases of goats in Ogbomoso town were diarrhea, mange and 
Table 1 Characteristics of goat produccrs in Ogbomoso town.

\begin{tabular}{|c|c|c|c|c|}
\hline \multirow{2}{*}{ Characteristics } & \multicolumn{2}{|c|}{ Major farms } & \multicolumn{2}{|c|}{ Household Owner } \\
\hline & Absolute figure & $\%$ & Absolute figure & $\%$ \\
\hline \multicolumn{5}{|l|}{ Sex of respondents } \\
\hline Male & 5 & 80 & 4 & 4.8 \\
\hline Female & 0 & 0 & 80 & 95.2 \\
\hline \multicolumn{5}{|l|}{ Age of respondents } \\
\hline $0-18$ & & & 2 & 2.4 \\
\hline $19-30$ & 3 & 60 & 13 & 15.7 \\
\hline $31-50$ & 2 & 40 & 44 & 53 \\
\hline$>50$ & 0 & 0 & 22 & 28.9 \\
\hline \multicolumn{5}{|l|}{ Form of business } \\
\hline Part time & 0 & 0 & 81 & 97.6 \\
\hline Full time & 5 & 100 & 2 & 2.4 \\
\hline \multicolumn{5}{|c|}{ Types of animal kept } \\
\hline $\begin{array}{l}\text { Goats } \\
\text { Sheep }\end{array}$ & 1 & 20 & 76 & 91.6 \\
\hline Mixed & 4 & 80 & 7 & 8.4 \\
\hline
\end{tabular}

Table 2 Feeding pattern of goats in Ogbomoso town

\begin{tabular}{lcccc}
\hline Characteristics & $\begin{array}{c}\text { Major farms } \\
\text { Absolute figure }\end{array}$ & $\%$ & Absolute figure & $\%$ \\
\hline Type of feed & & & & \\
Kitchen waste & 2 & 40 & 5 & 5.5 \\
$\quad$ Forage & 5 & 100 & 19 & 20 \\
Crop residue & 5 & 100 & 82 & 91.1 \\
Crop by product & 2 & 40 & 0 & 0 \\
Source of feed & & & & \\
$\quad$ Farm & 4 & 80 & 16 & 19.3 \\
$\quad$ Market & 1 & 20 & 45 & 54.2 \\
$\quad$ Processors & 0 & 0 & 7 & 8.4 \\
Kitchen wastes & 0 & 0 & 15 & 18.1 \\
\hline
\end{tabular}

Tolal observation for the type of feed is greater than $100 \%$ due to multiple responses. 
Table 3 Level of developments

\begin{tabular}{|c|c|c|c|c|}
\hline \multirow[b]{2}{*}{ Characteristics } & \multirow{2}{*}{$\begin{array}{l}\text { Major farms } \\
\text { Absolute figure }\end{array}$} & \multirow[b]{2}{*}{$\%$} & \multicolumn{2}{|c|}{ Household owners } \\
\hline & & & Absolute figure & $\%$ \\
\hline \multicolumn{5}{|c|}{ Access to extension agent } \\
\hline Yes & 2 & 40 & 10 & 12 \\
\hline No & 3 & 60 & 73 & 88 \\
\hline \multicolumn{5}{|c|}{ Access to agricultural journals } \\
\hline Yes & 3 & 60 & 3 & $3.6^{\circ}$ \\
\hline No & 2 & 40 & 80 & 96.4 \\
\hline \multicolumn{5}{|l|}{ Goat's manure } \\
\hline Spread on farm & 3 & 60 & 3 & 3.6 \\
\hline Throw it away & 2 & 40 & 80 & 96.4 \\
\hline
\end{tabular}

pneumonia. Among the major farms, foot and mouth rot, PPR, helminthiases were also prevalent.

Table 2 shows the type and sources of the feeds given to the goats. All the major farms feed forages and crop residues to the goats while $20 \%$ fed forages to the goats. The type of crop residues includes cassava peel, cowpea husk and corn starch meal residues. The types of forage given to the animals include Leucaena leucocephala, Gliricidia sepium, Centrosema pubescens, Panicum maximum and Bracharia brasilantha. Among the major farms 80\% get their feeds from the farms while $20 \%$ bought the crop residues from the market. About fifty-seven percent of the household owners of goats bought their feed from the market while $18.3 \%$ fed waste from the farm to the goat. Both parties of goat keepers fed their goats on a regular basis.

Household owners of goats did not practice control breeding while $80 \%$ of the major farms did not practice control breeding. Both parties practice loose buck mating. Large percentage of the goats had multiple births; the young do: gives birth to one kid initially and then star: giving birth to two or three kids afterwards. This is in agreement with previous reports on the prolificacy of West African breed of goats whict. are predominant in the area.

Table 3 shows the level of goat productiodevelopment in terms of access to extensio: services and agricultural journals. Eighty eigh: percent of household owners and $60 \%$ of majo: farms did not have access to extension services while majority of the major farms and very few household owners, $60 \%$ and $3.6 \%$ respectivel: had access to agricultural journals an magazincs. Other constraints to goat productio: in the area include: diseases, accidents, seasonality of feed supply, theft, destructive hab: of goat, and lack of capital and land. Similaconstraints have been reported in literature ( $\mathrm{Gef}^{-}$et.al; 1994, Doma et.al; 1999). Because of tr. high level of literacy reported, it was observethat $60 \%$ of the major farms made use of thi goat's manure to fertilize the soil while only $3.6^{\circ}$. of household owners utilized the manure. Ther 
is therefore the need to sensitize livestock farmers to sustainable agricultural practices for increased productivity of their livestock.

Goat production in Ogbomoso town was basically on a part-time basis. This is in agreement with Upton, (1988), that goats in the humid tropics are generally kept as a low cost adjunct to arable and tree crop production. This is probably due to the large investment capital required to raise goats on a large scale production. The distribution of goats in the area shows that the household owners are the major producers of goats in the area. This is in agreement with (Sumberg and Cassaday, 1985), who reported that $75 \%$ of the rural population keep small ruminants with an average herd size of two to four animals per household, the goats being commonly kept than the sheep. The productivity of the goats in the area was very low due to the free-range system of production. This is because under this system the animals received minimal inputs in terms of nutrient content of the feed and breeding control programme. This is in agreement with the reports of Ademosun (1993) and Gefu et.al; 1994.

The goat producers in the areas had access to veterinary services, which would help to reduce the rate of mortality among the goats. A lapse in the veterinary services provided was that the household owners could only afford the services of "quacks", which explains why the cost of treatment was low compare to major farms. Crop residue are the most common feed type fed to the goats, although these feed resources are abundant and cheap sources of nutrients for ruminants especially during crop growing season.
Nevertheless, they are generally low in nutrients (Nicholson, 1984). This generally limits optimum productivity of goats in the area.

\section{Conclusion}

Goat keeping is a common practice among the people of Ogbomoso town especially among the households. Free range system of production was mostly used and the breed of goats kept was limited to the West Africa Dwarf goat that is adaptable to the area. Goats were kept to supplement the family income and for consumption during the festive seasons and special occasions. The level of development of goat production in the area can be said to be low because the services of the extension agents in the area was virtually none existing. Therefore, the gap between the goats' producers on the field and researchers in the laboratory is not bridged.

Also, the management system used in raising goats is poor; they tend to leave the production of goat more to chance than well-organized management. The gene pool of the goats in the area are not being improved; because no form of genetic improvement was done due to lack of controlled breeding practice. The constraints to goat production were seasonality of feed supply, accidents, theft, poor management system and disease. Goat keepers should provide housing for the goats or practice tethering, to reduce the occurrence of theft and accidents.

\section{References}

Ademosun A.A. 1993. The scope for improved small ruminants' production in humid zone of west and central Africa: The 
approach of the West Africa dwarf goat project. In: Smith O.B and Bosman H.G (Eds). Goat production in the humid tropics. Proceeding of an international workshop at the Obafemi Awolowo University, Ile-Ife Nigeria, July 1992, page 2-12. Pudoc Scientific Publishers, Wageningen, The Netherlands.

Alimi T, 1987. The prospect of large scale commercial dwarf goat production in Southwestern Nigeria: In: Goat Production in the Humid Tropics. Smith O.B and Bosman H.G (Eds). Proceeding of an international workshop at the Obafemi Awolowo University, Ile Ife Nigeria. July 1987. 1987, 154:20-24. Pudoc Scientific Publishers, Wageningen, The Netherlands

\section{Doma, U.D, Mohammed, LK, and Umeh, A.P. 1999.} Observations on the characteristics of small holder sheep and goat management practices in old Bauchi state. Trop. J. Anim. Sci. 2: 125-130.

Dominique, B.M.F, Dellow D.W and Barry T.N 1991. Voluntary intake and rumen digestion of low quality roughage by goats and sheep. J.Agric Sci. (Camb) 117: $111-120$

FAO, 1985. Production yearbook 38 Rome, Italy

Gefu J.O, Adu I.F. Alawa C.B.I. and Magaji S.O. 1994. Characteristics of smallholder sheep and goat management practices in southeast Nigeria: Observations from Anambra State. Nig J. Anim. Prod. 21 : 127-134.

Howe J.C, Barry T.N. and Popay A.I, 1988. Voluntary intake and digestion of gorse by goats and sheep. J.Agric Sci. (Camb), 111:107-114.

Mattewman, R.W. 1980. Small ruminant production in the humid tropical zone of Southern Nigeria. Trop. Anim. Hlth. Prod. 12: 234-242

Nicholson J.W.G. 1984. Digestibility, nutritive value and feed intake. Chapter 12. In: Straw and other fibrous feed (.Sundsol and E. Owen, editors).Elsevier, Amsterdam.

Odeyinka, S.M. 1996. Survey of urban small ruminant production system in Osun state. Nig. J. Agric. Tech. 5; 44-48

Peacock, C. 1996. Improving goat production in the tropics (Manual for development workers). Oxfam/Farm-Africa, Ppl-7.

Sumberg, J.E and Cassaday. K. 1985. Sheep and goats in the humid west Africa. In: Sumberg, J.E and Cassaday. K. (Eds) Sheep and goats in humid West Africa. Proceeding of a workshop on small ruminant production system in humid zone West Africa. Ibadan, Nigeria, 23. 26 January 1983. ILCA Addis Ababa. Ethiopia. Pp3-5 
Sumberg, J.E. and Mack, S.O. 1985. Village production of West African Dwarf goat and sheep in Nigeria. Trop. Anim. Hlth Prod. 17: 135-140

Upton M. 1987. Goat production in the humid tropics- Actual and potential contribution to Agricultural development. Smith O.B and Bosman H.G (Eds). Proceeding of an international workshop at the Obafemi
Awolowo University, lle Ife Nigeria. July 1987. 1987, 11-19. Pudoc Scientific Publishers, Wageningen, The Netherlands

(Received 30 July 2003; Accepted 13 October, 2004). 